\title{
Molecular diversity of exotic durian (Durio spp.) germplasm: a case study of Kalimantan, Indonesia
}

\author{
Dindin Hidayatul Mursyidin ${ }^{1 *} \mathbb{D}$, Muhammad Irfan Makruf ${ }^{1}$, Badruzsaufari ${ }^{1}$ and Aidi Noor $^{2}$
}

\begin{abstract}
Background: Durian of Indonesia, specifically Durio zibethinus, is a potential agricultural commodity for domestic and international markets. However, its quality is still less competitive or significantly lower to fulfill the export market, compared to a similar one from other countries. This study aimed to determine and analyze the genetic diversity and relationship of the exotic durian (Durio spp.) germplasm originally from Kalimantan, Indonesia, using the rbcL marker.

Results: Based on this marker, the durian germplasm has a low genetic diversity $(\pi \%=0.24)$. It may strongly correspond with the variability sites or mutation present in the region. In this case, the rbcL region of the durian germplasm has generated 23 variable sites with a transition/transversion (Ti/Tv) bias value of 1.00. However, following the phylogenetic and principal component analyses, this germplasm is separated into four main clades and six groups, respectively. In this case, D. zibethinus was very closely related to D. exleyanus. Meanwhile, D. lowianus and D. excelsus were the farthest. In further analysis, 29 durians were very closely related, and the farthest was shown by Durian Burung (D. acutifolius) and Kalih Haliyang (D. kutejensis) as well as Pampaken Burung Kecil (D. kutejensis) and Durian Burung (D. acutifolius) with a divergence coefficient of 0.011 . The Pearson correlation analysis confirms that 20 pairs of individual durians have a strong relation, shown by, e.g., Maharawin Hamak and Durian Burung as well as Mantuala Batu Hayam and Durian Burung Besar.
\end{abstract}

Conclusion: While the durian has a low genetic diversity, the phylogenetic analyses revealed that this germplasm originally from Kalimantan, Indonesia, shows unique relationships. These findings may provide a beneficial task in supporting the durian genetic conservation and breeding practices in the future, locally and globally.

Keywords: DNA barcoding, Genetic diversity, Malvaceae, Phylogenetic relationship, Plant breeding

\section{Background}

Durian, specifically Durio zibethinus, is a potentially valuable agricultural commodity for domestic and international markets [1]. Even it is a prospective export commodity today. For example, Indonesia, one of the world's biggest durian producers, was able to sell this fruit to numerous other countries, including several Middle

\footnotetext{
*Correspondence: dindinhm@gmail.com

${ }^{1}$ Laboratory of Genetics and Molecular Biology, Faculty of Mathematics and Natural Sciences, University of Lambung Mangkurat, Jl. A. Yani Km. 36, Banjarbaru, South Kalimantan 70714, Indonesia

Full list of author information is available at the end of the article
}

Eastern countries with a total value of 232,000 USD in 2020 [2]. Similarly, this country has generated over 1.19 million metric tons of durian in the same year [3]. However, compared to a similar commodity from two adjacent nations, i.e., Thailand and Malaysia, the quality of Indonesian durians is still less competitive (significantly lower) to fulfill the export market [4]. As a result, various strategic plans must be included in the breeding program to improve the quality of durian fruit, particularly.

Germplasm collection is a vital component of plant breeding program success or the development of new superior cultivars [5]. Around 18 of the world's 27 durian species, including their wild relatives, have been 
discovered in Indonesia. There are even 16 species that are considered endemic, and the Kalimantan is the Indonesian island with the highest durian genetic diversity [6]. According to Uji [7], the nine edible durian species present in this region with delicious flesh taste and unique fruit characteristics, including $D$. dulcis, $D$. excelsus, $D$. grandiflorus, D. graveolens, $D$. kutejensis, D. lowianus, $D$. oxleyanus, $D$. testudinarum, and D. zibethinus. In addition, these durians have other advantages, such as being resistant to diseases, especially patch canker, and having a high tolerance for environmental challenges, such as acid soil [6]. As a result, the germplasm is useable as a parent in a breeding effort.

Germplasm characterization is also crucial to aiding the durian plant breeding initiative or generating new superior cultivars [5]. However, durian germplasm and its relatives have only been characterized using morphological markers so far [1]. While these markers have advantages, they are frequently multigenic and heavily impacted by environmental factors [8]. Furthermore, morphological ones are inefficient since they can only be applied to mature plants, wait for the generative phase (flowers), and are time-consuming to apply [1]. The genetic diversity and relationships of durians have already been studied using various molecular markers, including RAPD $[1,9,10]$, SSR, and ISSR $[11,12]$. However, because these markers are highly subjective, the study is less precise [13]. According to Wu et al. [14], these markers are also poor consistency, limited repeatability, or complicated operation limit their effectiveness.

This study aimed to determine and analyze the genetic diversity and relationship of the exotic durian (Durio spp.) germplasm originally from Kalimantan, Indonesia, using the $r b c \mathrm{~L}$ marker. Following Moura et al. [15], this marker shows high universality and amplification success. Also, this marker has generated a relatively highquality output and unbias sequence data $[13,16]$. So it is useful for discriminating Angiosperms or germplasm with close genetic relationships [17]. In partial, this marker has been applied for various plant germplasm, such as Oryza sativa [18], Amorphophallus [19], Flacourtia inermis [20], and Ilex [21]. As a result, the findings of this study can be applied to help future durian germplasm breeding initiatives, both locally and globally.

\section{Methods \\ Plant samples}

In this study, we have used a total of eighteen samples of durian (Durio spp.) germplasm, excluding an outgroup (Table 1). Most of the durian samples were collected from South Kalimantan, Indonesia, using a purposive sampling method (Fig. 1). Meanwhile, an outgroup (Bombax ceiba) was obtained from the GenBank database.

Table 1 List of exotic durian (Durio spp.) germplasm used in this study, including their origin, GenBank accession number, and rbcL sequence length

\begin{tabular}{|c|c|c|c|c|c|c|}
\hline Local name & Code & Species & Origin & Ordinate & Acc. Num. & $r b c L(b p)$ \\
\hline Durian Likol & 1 & D. zibethinus & Tabalong, South Kalimantan & $1^{\circ} 37^{\prime} 04.84^{\prime \prime S} \mathrm{~S} ; 115^{\circ} 31^{\prime} 14.65^{\prime \prime} \mathrm{E}$ & MZ479693 & 566 \\
\hline Durian Sahang & 2 & D. zibethinus & Tabalong, South Kalimantan & $1^{\circ} 51^{\prime} 51.49^{\prime \prime S} \mathrm{~S} ; 115^{\circ} 34^{\prime} 05.19^{\prime \prime} \mathrm{E}$ & MZ479694 & 571 \\
\hline Durian Si Japang & 3 & D. zibethinus & Banjar, South Kalimantan & $3^{\circ} 29^{\prime} 11.54^{\prime \prime} \mathrm{S} ; 114^{\circ} 58^{\prime} 31.50^{\prime \prime} \mathrm{E}$ & MZ479695 & 529 \\
\hline Kalih Haliyang & 4 & D. kutejensis & Balangan, South Kalimantan & $2^{\circ} 19^{\prime} 33.75^{\prime \prime S} \mathrm{~S} ; 15^{\circ} 36^{\prime} 55.70^{\prime \prime} \mathrm{E}$ & MZ479679 & 571 \\
\hline Kamundai & 5 & D. kutejensis & Tabalong, South Kalimantan & $1^{\circ} 51^{\prime} 51.49^{\prime \prime S} \mathrm{~S} 115^{\circ} 34^{\prime} 05.19^{\prime \prime} \mathrm{E}$ & MZ479691 & 564 \\
\hline Lai Lidung & 6 & D. kutejensis & Kutai, East Kalimantan & $0^{\circ} 08^{\prime} 01.20^{\prime \prime} \mathrm{S} ; 116^{\circ} 36^{\prime} 29.40^{\prime \prime} \mathrm{E}$ & MZ479692 & 566 \\
\hline Pampaken & 7 & D. kutejensis & Tabalong, South Kalimantan & $1^{\circ} 51^{\prime} 51.49^{\prime \prime S} \mathrm{~S} ; 15^{\circ} 34^{\prime} 05.19^{\prime \prime} \mathrm{E}$ & MZ479690 & 568 \\
\hline Pampaken Burung Kecil & 8 & D. kutejensis & South Hulu Sungai, South Kalimantan & $2^{\circ} 43^{\prime} 18.34^{\prime \prime S} ; 115^{\circ} 12^{\prime} 02.78^{\prime \prime} \mathrm{E}$ & MZ479683 & 568 \\
\hline Durian Daun & 9 & D. lowianus & South Hulu Sungai, South Kalimantan & $2^{\circ} 43^{\prime} 18.34^{\prime \prime} \mathrm{S} ; 115^{\circ} 12^{\prime} 02.78^{\prime \prime} \mathrm{E}$ & MZ479686 & 564 \\
\hline Durian Malutu & 10 & D. lowianus & South Hulu Sungai, South Kalimantan & $2^{\circ} 52^{\prime} 43.50^{\prime \prime S} ; 115^{\circ} 16^{\prime} 40.19^{\prime \prime} \mathrm{E}$ & MZ479684 & 568 \\
\hline Lahung Alang & 11 & D. lowianus & Balangan, South Kalimantan & $2^{\circ} 19^{\prime} 33.75^{\prime \prime S} \mathrm{~S} ; 15^{\circ} 36^{\prime} 55.70^{\prime \prime} \mathrm{E}$ & MZ479688 & 568 \\
\hline Durian Burung Besar & 12 & D. excelsus & Balangan, South Kalimantan & $2^{\circ} 19^{\prime} 33.75^{\prime \prime S} ; 115^{\circ} 36^{\prime} 55.70^{\prime \prime} \mathrm{E}$ & MZ479680 & 578 \\
\hline Mantuala Batu Hayam & 13 & D. excelsus & Central Hulu Sungai, South Kalimantan & $2^{\circ} 40^{\prime} 11.84^{\prime \prime} \mathrm{S} ; 115^{\circ} 29^{\prime} 49.37^{\prime \prime} \mathrm{E}$ & MZ479682 & 570 \\
\hline Maharawin Hamak & 14 & D. oxleyanus & Banjar, South Kalimantan & $2^{\circ} 45^{\prime} 33.03^{\prime \prime S} \mathrm{~S} ; 15^{\circ} 20^{\prime} 56.21^{\prime \prime} \mathrm{E}$ & MZ479681 & 527 \\
\hline Karantungan Besar & 15 & D. oxleyanus & Katingan, Central Kalimantan & $0^{\circ} 58^{\prime} 33.02^{\prime \prime S} \mathrm{~S}_{1} 112^{\circ} 48^{\prime} 37.98^{\prime \prime} \mathrm{E}$ & MZ479689 & 565 \\
\hline Durian Burung & 16 & D. acutifolius & Balangan, South Kalimantan & $2^{\circ} 19^{\prime} 33.75^{\prime \prime S} ; 115^{\circ} 36^{\prime} 55.70^{\prime \prime} \mathrm{E}$ & MZ479678 & 527 \\
\hline Lahung & 17 & D. dulcis & Balangan, South Kalimantan & $2^{\circ} 19^{\prime} 33.75^{\prime \prime} \mathrm{S} ; 115^{\circ} 36^{\prime} 55.70^{\prime \prime} \mathrm{E}$ & MZ479687 & 585 \\
\hline Durian Kura-Kura & 18 & D. testudinarium & Sekadau, West Kalimantan & $0^{\circ} 18^{\prime} 54.35^{\prime \prime S} \mathrm{~S} ; 10^{\circ} 51^{\prime} 19.05^{\prime \prime} \mathrm{E}$ & MZ479685 & 568 \\
\hline Indian Kapok & 19 & Bombax ceiba & Kerala, India & - & KY556637 & 747 \\
\hline
\end{tabular}

${ }^{a}$ An outgroup, obtained from GenBank database 


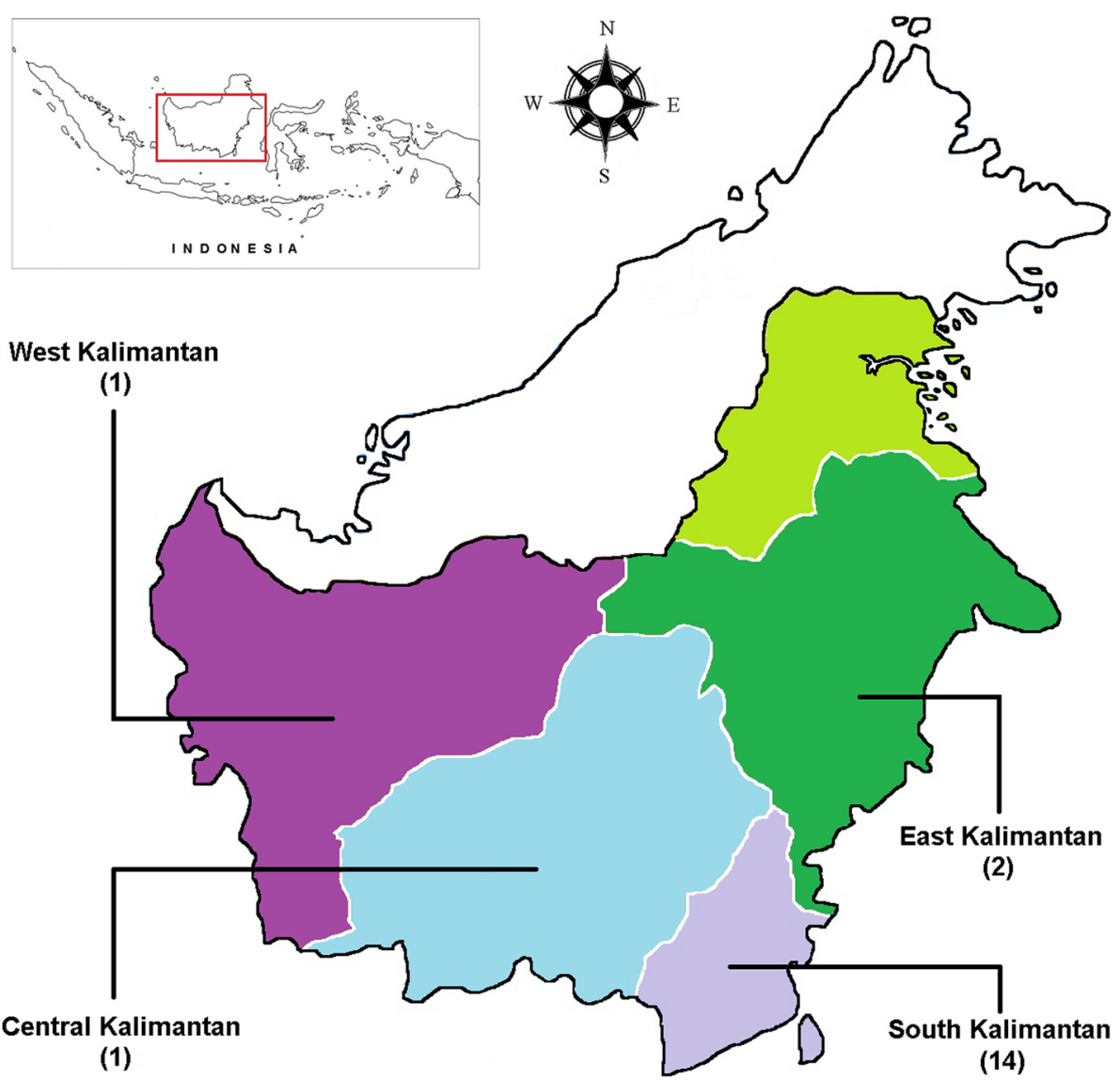

Fig. 1 Map of Kalimantan, Indonesia, showing sampling locations where eighteen durians were collected and used in this study. The list of durian samples and their complete origin are shown in Table 1

\section{DNA assay}

The DNAs were extracted from the durian leaves using a combined commercial kit from Molecular Research Center Inc., USA (DNAZol@Direct) and Geneaid Biotech Ltd., Taiwan (GP100). The genetic materials were then quantified using a UV-VIS spectrophotometer (NanoVue, GE Healthcare, UK) and amplified by a pair of $r b c \mathrm{~L}$ primers, namely $r b c \mathrm{~L}-\mathrm{F}$ (5'-ATGTCACCACAA ACAGAGACTAAAGC- $3^{\prime}$ ) and $r b c \mathrm{~L}-\mathrm{R}$ (5'-GTAAAA TCAAGTCCACC RCG-3') [22]. Amplification was employed in the total volume reaction of $25 \mu \mathrm{L}$, consisting of $2 \mu \mathrm{L}$ DNA template (20 ng), $1 \mu \mathrm{L}$ for each primer $(0.2 \mu \mathrm{mol})$, and $22 \mu \mathrm{L}$ of MyTaq HS Red Mix (Bioline, UK). This reaction was setting with the following conditions: initial denaturation at $94{ }^{\circ} \mathrm{C}$ for $5 \mathrm{~min}$; followed by 35 cycles of denaturation at $94{ }^{\circ} \mathrm{C}$ for $30 \mathrm{~s}$, annealing at $48{ }^{\circ} \mathrm{C}$ for $30 \mathrm{~s}$, and extension at $72{ }^{\circ} \mathrm{C}$ for $45 \mathrm{~s}$; and a final extension at $72{ }^{\circ} \mathrm{C}$ for $7 \mathrm{~min}$ [18]. The amplicon (DNA product) was then separated on $2 \%$ agarose gel electrophoresis, including a $1 \mathrm{X}$ TBE buffer solution and DNA stain (GelRed, Biotium Inc., USA), and observed on
UV transilluminator. The DNA product was then purified and sequenced by 1st Base Ltd., Malaysia, using the Sanger method, bi-directionally. All sequence $(r b c \mathrm{~L})$ targets were deposited in GenBank with accession numbers of MZ479678-MZ479695 (Table 1).

\section{Data analysis}

The $r b c \mathrm{~L}$ sequences of durian were refined manually to a reconstructed consensus using the MEGA-X software [23]. These sequences were then aligned using ClustalOmega [24] and MultAlin [25]. The genetic diversity of this germplasm was determined using the nucleotide diversity index $(\pi \%)$ with the following categories: $0.1-0.4$ is low, $0.5-0.7$ is moderate, and $0.8-2.00$ is high [26]. The phylogenetic analysis was done by maximum likelihood (ML) and neighbor-joining (NJ) methods, with the assistance of MEGA-X [23]. The internal node of each phylogenetic tree was evaluated by the bootstrap method (1000 replicates) [27]. The genetic relationship was also determined using the principal component analysis (PCA) by the MVSP ver. 3.1 [28]. The AMOVA and 
evolutionary divergence among sequences were analyzed using the Kimura 2-parameter model [29]. In addition, the F-statistics at the molecular level were calculated among species (populations), and their significance was also tested by a permutation procedure, using 2000 permutations. These analyses were conducted by Arlequin [30]. The Pearson correlation $(r)$ analysis, by the criteria of weak $(r \leq 0.35)$, moderate $(r=0.36-0.67)$, and strong $(r>0.68)$, was finally applied to confirm the differences in genetic structure between durian samples [31].

\section{Results}

The $r b c L$ region of durians and its genetic diversity

The durian $r b c L$ region was successfully amplified. The amplification results show that this region has a size of approximately $650 \mathrm{bp}$ (Fig. 2). After sequencing, each durian (Durio spp.) sample had a different $r b c \mathrm{~L}$ sequence length, ranging from $527-578$ bp (Table 2). The multiple sequence alignment is presented in Fig. 3. Based on Table 2, this region has $44.39 \%$ of GC content, 23 variable sites, five Parsimony informative sites, six singleton sites, and 0.51 transition/transversion bias values. Table 3 shows detailed information on the Parsimony informative site's position on the $r b c \mathrm{~L}$ region of the durian germplasm. In this case, only two mutations were present in this region, namely substitution-transition and substitution-transversion (Table 3) or no indels therein (Table 2). Furthermore, following this region, the durian germplasm has a nucleotide diversity $(\pi \%)$ of 0.24 , with the AMOVA shown in Table 4. Following Table 4, at inter-species, the durian germplasm has a lower variation (5.62\%) than the intra-species level (94.38\%).

\section{Genetic relationship and divergence}

The durian (Durio spp.) germplasm from Kalimantan, Indonesia, shows unique relationships. This uniqueness lies in the number and composition of durian members in each clade formed. In general, following the maximum likelihood (ML) and neighbor-joining (NJ) methods, this
Table 2 Genetic information of $r b c L$ sequences of durian (Durio spp.) germplasm

\begin{tabular}{ll}
\hline Parameter & rbcL \\
\hline Range of sequence length (bp) & $527-578$ \\
GC content (\%) & 44.30 \\
Number of variable sites $(S)$ & 23 \\
Number of parsimony informative sites & 5 \\
Number of singleton sites & 6 \\
Number of indels & 0 \\
Transition/transversion bias value $(R)$ & 1.00 \\
Nucleotide diversity $(\pi \%)$ & 0.24 \\
\hline
\end{tabular}

germplasm is grouped into four main clades (Figs. 4 and 5 , respectively). In this case, the first clade (I) is the largest, composed of nine durian germplasm for ML and ten for NJ. Clade II is the next largest consisting of five durian samples for ML and four for NJ. Clades III and IV consisted of two individuals, both ML and NJ. Interestingly, most of the durian samples were consistent in the same clade, both for ML and NJ, except for Durian Si Japang (D. zibethinus), which belongs to clade II in ML and clade I in NJ (Table 5).

The PCA has generated differences in germplasm grouping. In this case, the durians have separated into six groups (Fig. 6), where group I was a largest and compose by six durians, i.e., Pampaken, Pampaken Burung Kecil, Malutu, Kura-Kura, Lahung Alang, and Si Japang. Meanwhile, other groups have consisted of two (IV and V) and three (II, III, and VI) members only (Fig. 6).

The divergence analysis (Table 6) showed that by species group, $D$. zibethinus was very closely related to $D$. exleyanus. Meanwhile, the farthest shows by $D$. lowianus and D. excelsus. Overall, the divergence analysis (Table 7) show a relationship between all samples (individuals), where 29 durian pairs are very closely related, and the farthest shown by Durian Burung (D. acutifolius) and Kalih Haliyang (D. kutejensis), and Pampaken

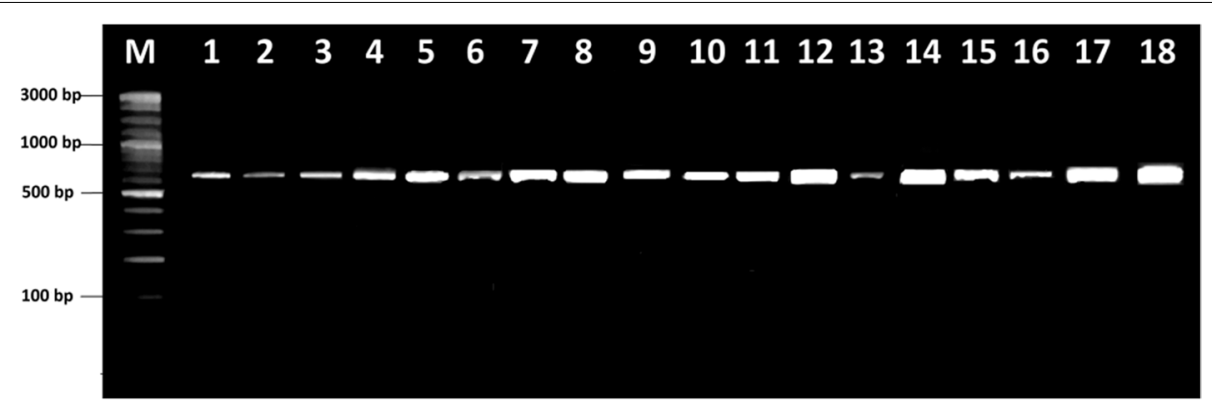

Fig. 2 Electrophoresis profile showing PCR products of exotic durian germplasm generated by the rbcL marker. The name of each durian sample is shown in Table 1 


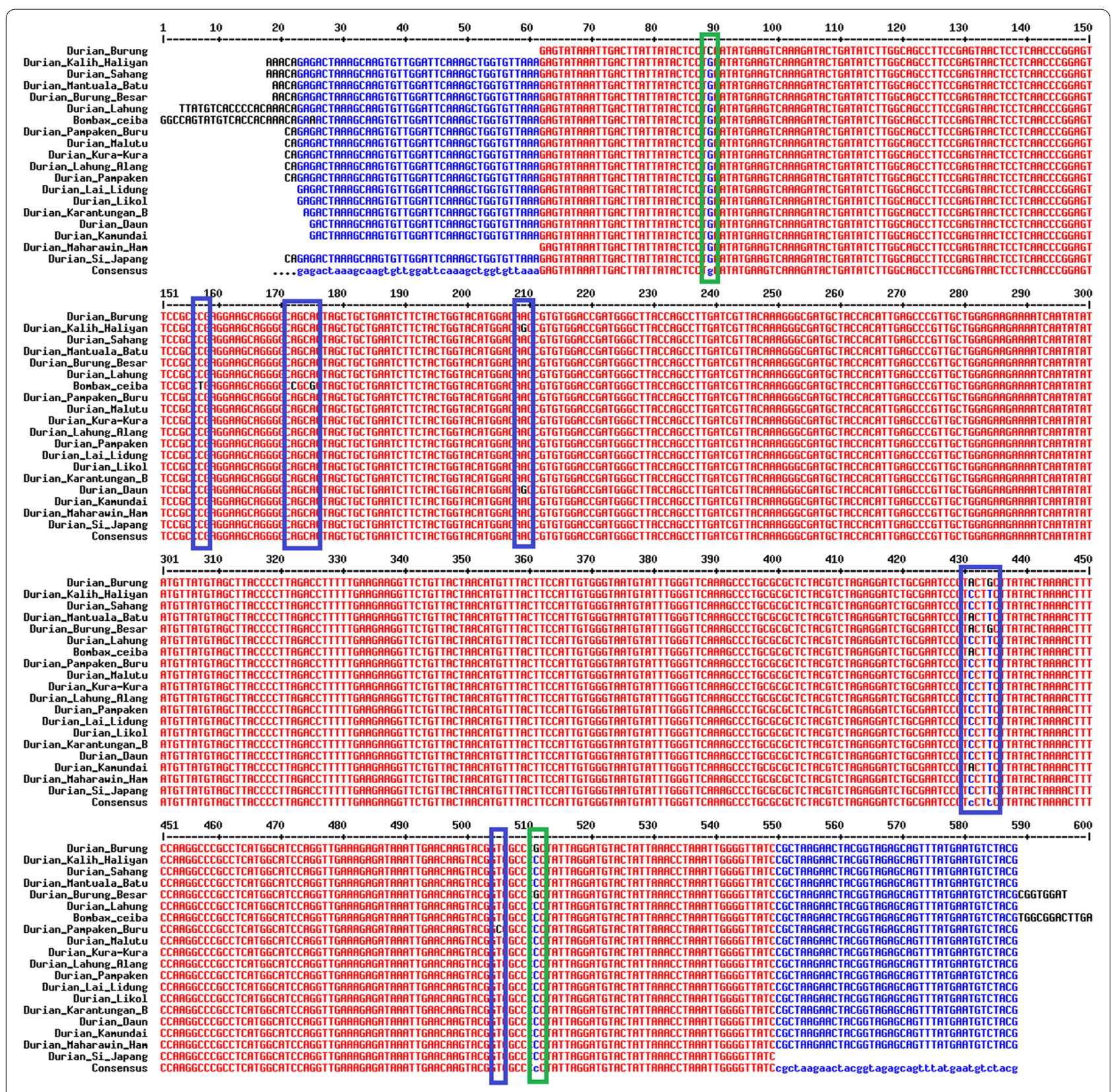

Fig. 3 Multiple sequence alignment of $r b c L$ of exotic durian (Durio spp.) germplasm, showing several mutational events, i.e., transition (green closed rectangle) and transversion (blue closed rectangle)

Burung Kecil (D. kutejensis) with Durian Burung (D. acutifolius) as well, at a divergence coefficient of 0.011 . The Pearson correlation analysis confirms that twenty pairs of individual durians have a strong relation (Fig. 7), for example, between Maharawin Hamak and Durian Burung as well as Mantuala Batu Hayam and Durian Burung Besar (Fig. 7).

\section{Discussion}

\section{The $r b c L$ region of the durian}

The ribulose-1, 5-bisphosphate carboxylase/oxygenase, or $r b c \mathrm{~L}$, is a functional gene in the chloroplast genome engaged primarily in plant photosynthesis [32]. This gene is found in the chloroplast genome's large single-copy (LSC) region and exhibits high similarity across plant germplasm [33]. According to Singh and Banerjee [34], this gene has a 600-800 nucleotide intergenic spacer. The 
Table 3 Parsimony informative sites on the rbcL sequences of durian (Durio spp.) germplasm

\begin{tabular}{|c|c|c|c|c|c|c|}
\hline \multirow[t]{2}{*}{ Local name } & \multirow[t]{2}{*}{ Species } & \multicolumn{5}{|c|}{ Nucleotide position } \\
\hline & & $209^{b}$ & $431^{b}$ & $434^{b}$ & $511^{\mathrm{a}}$ & $748^{a}$ \\
\hline Durian Likol & D. zibethinus & . & C & $\mathrm{T}$ & C & . \\
\hline Durian Sahang & D. zibethinus & . & C & $\mathrm{T}$ & C & G \\
\hline Durian Si Japang & D. zibethinus & & $C$ & $\mathrm{~T}$ & C & G \\
\hline Kalih Haliyang & D. kutejensis & G & C & $\mathrm{T}$ & $C$ & G \\
\hline Kamundai & D. kutejensis & . & . & $\mathrm{T}$ & $C$ & . \\
\hline Lai Lidung & D. kutejensis & . & $C$ & $\mathrm{~T}$ & $C$ & . \\
\hline Pampaken & D. kutejensis & . & C & $\mathrm{T}$ & $C$ & G \\
\hline Pampaken Burung Kecil & D. kutejensis & . & C & $\mathrm{T}$ & $C$ & G \\
\hline Durian Daun & D. lowianus & G & C & $\mathrm{T}$ & C & \\
\hline Durian Malutu & D. lowianus & . & C & $\mathrm{T}$ & C & G \\
\hline Lahung Alang & D. lowianus & & C & $\mathrm{T}$ & C & G \\
\hline Durian Burung Besar & D. excelsus & & & & . & . \\
\hline Mantuala Batu Hayam & D. excelsus & & & $\mathrm{T}$ & $C$ & . \\
\hline Maharawin Hamak & D. oxleyanus & . & C & $\mathrm{T}$ & C & - \\
\hline Karantungan Besar & D. oxleyanus & . & C & $\mathrm{T}$ & C & G \\
\hline Durian Burung & D. acutifolius & . & . & . & . & \\
\hline Lahung & D. dulcis & . & C & $\mathrm{T}$ & $C$ & . \\
\hline Durian Kura-Kura & D. testudinarium & . & $C$ & $\mathrm{~T}$ & $C$ & G \\
\hline Indian Kapok* & Bombax ceiba & & & $\mathrm{T}$ & C & . \\
\hline Consensus & & A & A & G & G & $C$ \\
\hline
\end{tabular}

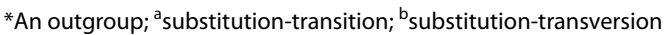

Table 4 The AMOVA for durian (Durio spp.) germplasm, both inter- and intra-species levels

\begin{tabular}{lllll}
\hline Source of variation & Sum of square & Variance components & Percentage variation & Fixation indices \\
\hline Among populations (inter-species) & 1923.89 & 9.75 & 5.62 & $F_{\text {IS }}=1.00000$ \\
$\begin{array}{l}\text { Among individuals within populations (intra- } \\
\text { species) }\end{array}$ & 3931.00 & 163.79 & 94.38 & $F_{\mathrm{ST}}=0.05618$ \\
$\begin{array}{l}\text { Within individuals } \\
\text { Total }\end{array}$ & 0.00 & 0.00 & 0.00 & $F_{\mathrm{IT}}=1.00000$ \\
\hline
\end{tabular}

$r b c \mathrm{~L}$ gene contains around 1400 nucleotides that code for the large subunit protein, and the length varies significantly among flowering plants or Angiosperm [35].

In this study, the $r b c \mathrm{~L}$ region of durians has different lengths, ranging from 527 to $578 \mathrm{bp}$ (Table 2). These differences, both partial and complete, have been reported by several researchers. For example, Kumekawa et al. [36] have reported that durian (D. zibethinus) has a partial $r b c \mathrm{~L}$ of $250 \mathrm{bp}$, and Amandita et al. [37] about $500 \mathrm{bp}$. In complete, this germplasm has the $r b c \mathrm{~L}$ sequence of 1428 bp [38].

Further, a new DNA barcoding motif was discovered in the multiple sequence alignment of the $r b c \mathrm{~L}$ of durians, in which a conserved region is introduced by polymorphism or other mutational events (Fig. 3). Based on Table 2, the $r b c \mathrm{~L}$ durians of Kalimantan showed 23 variable sites or mutational events, and all are substitutions (transition-transversion), and no indels are present. According to Clegg [39], complete codon insertions/deletions are occasionally found in the gene, demonstrating a conservative pattern of nucleotide replacement. In general, grasses and other plant species such as Orchidales, Liliales, Bromeliales, and Arecales have a $>5$-fold differential in $r b c \mathrm{~L}$ substitution rate [39].

According to Dong et al. [40], this gene represents distinctions in molecular evolution mode and tempo in angiosperms, monocotyledons, Gramineae, and Elymus. In another study, the inter/intrageneric levels of $r b c \mathrm{~L}$ were highly efficient in Cornaceae, Cupressaceae, Ericaceae, and Graniaceae [34]. The $r b c \mathrm{~L}$ gene evolved more 


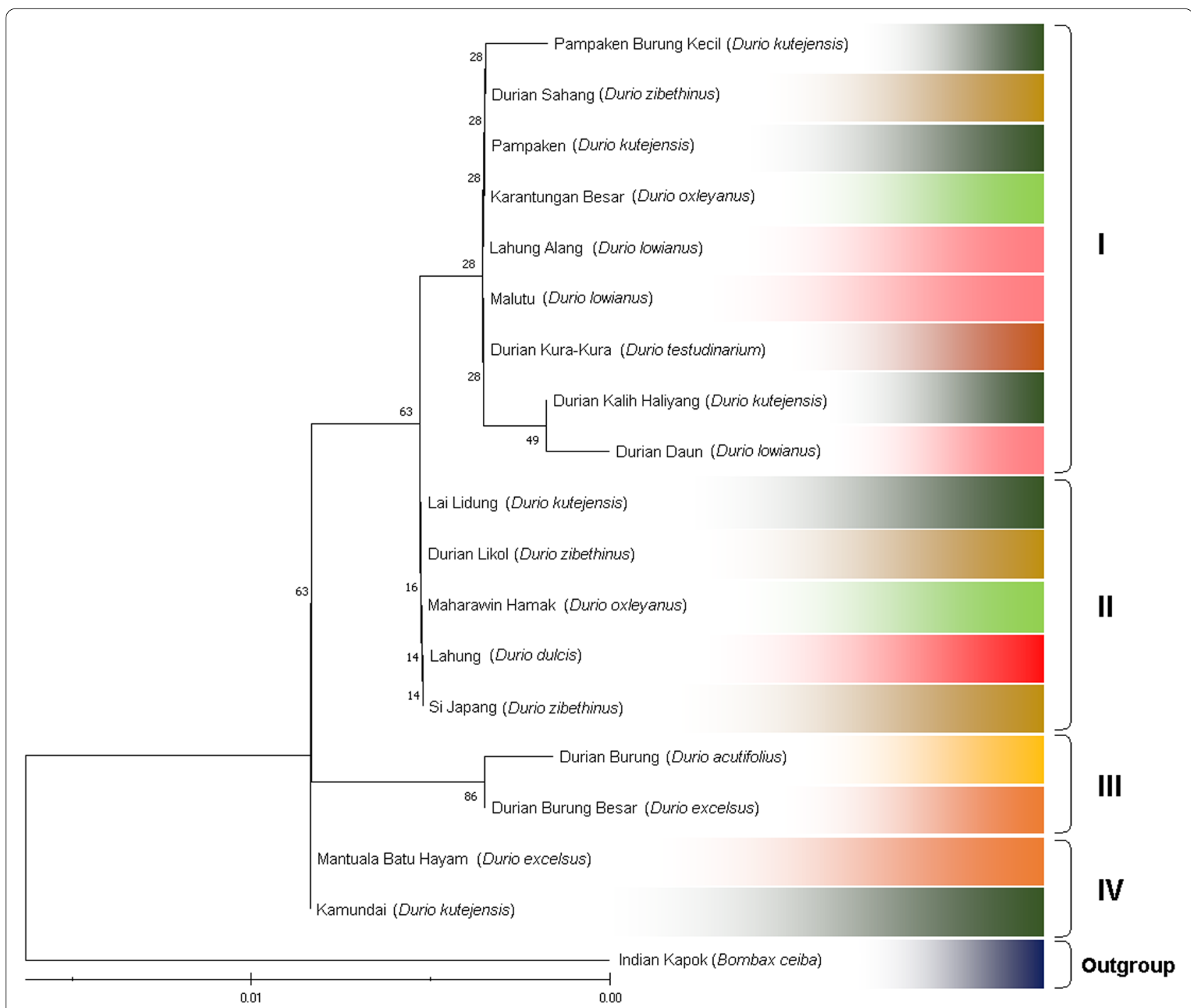

Fig. 4 Genetic relationship of exotic durian (Durio spp.) germplasm revealed by maximum likelihood (ML) and bootstrap analyses for 1000 replicates

quickly in annual plants, particularly in the Asteridae and Poaceae families, and was dubbed "most morphologically advanced forms" in these families [41].

\section{Genetic diversity and its benefits}

In this study, exotic durian (Durio spp.) germplasm originally from Kalimantan, Indonesia, has a low genetic diversity, shown by nucleotide diversity $(\pi \%)$ of 0.24 (Table 2). The low level of genetic diversity may be attributed to a combination of founder effects and subsequent bottlenecks encountered in its short domesticated history [42]. While the founder effect is a ubiquitous domestication bottleneck, millennia of cultivation and dissemination into new habitats have provided a considerable opportunity in selecting novel diversity in most crops [42].

Referred to Teixeira and Huber [43], low genetic diversity is often interpreted as an indicator of inbreeding depression and increased genetic drift. In other words, inbreeding, genetic drift, restricted gene flow, and small population size contribute to a genetic diversity reduction. Accordingly, populations lacking genetic diversity often exhibit an increased extinction rate [44]. Ujvari et al. [45] also reported that a decline in genetic diversity is linked to an increased risk of inbreeding depression, resulting in decreased growth rate, fertility, fecundity, and offspring viability, as well as in increased vulnerability to pathogens. Furthermore, a loss of genetic diversity 


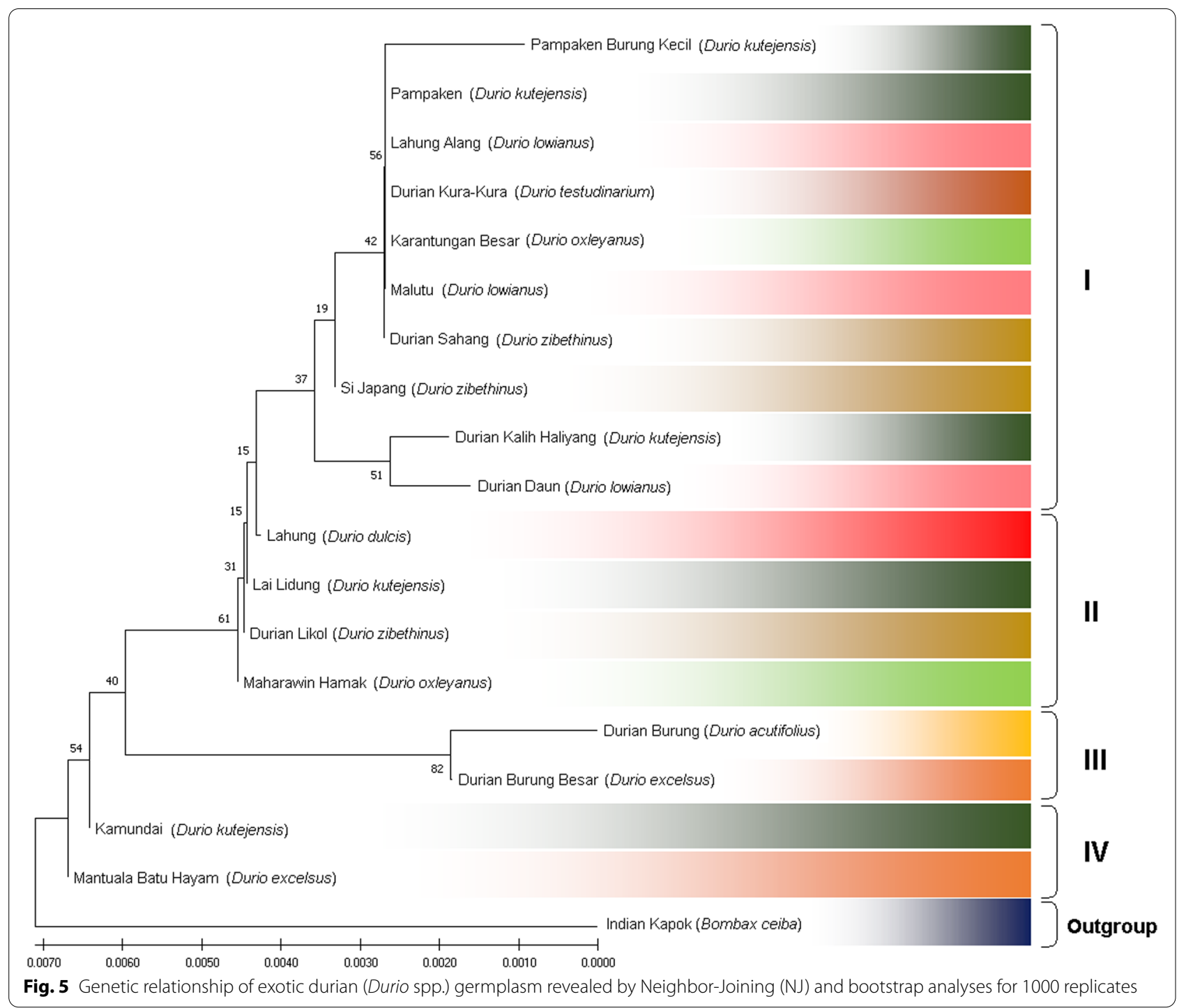

would harm individual fitness with increased susceptibility to disease and parasites [44] and limits a population's ability to respond to threats in reduced long- and shortterm survival of endangered species [46].

Compared to other studies with similar markers used, durian (Durio spp.) germplasm from this region has a high diversity. For example, tidal swamp rice (Oryza sativa) shows a genetic diversity of 0.086 . According to Teixeira and Huber [43], high levels of genetic diversity are beneficial to promoting population survival and guaranteeing the adaptive potential of natural populations in the face of rapidly changing environmental pressures. These principles are reflected in strategies such as genetic rescue, where the genetic diversity of a threatened or endangered population is increased by facilitating gene flow from a population with high levels of diversity [43].
However, emerging genetic diversity strongly correlated with the polymorphic or mutation found in a target region. According to Frankham et al. [47], genetic diversity and mutational events are two things that are related. In this study, the $r b c \mathrm{~L}$ region of the durian germplasm has generated 23 variable sites with a transition/transversion (Ti/Tv) bias value of 1.00 (Table 2). Multiple alignments revealed that transversion is more than transition (Fig. 3 and Table 3). Guo et al. [48] have reported that the first mutation is a more frequent encounter in this sequence and has higher regulatory effects than transitions. However, a pattern of the last mutation is favored several times over transversions is commonly occur in molecular evolution $[49,50]$.

Regardless of the presence of mutations in the $r b c \mathrm{~L}$ sequence of durians, genetic diversity is essential for plant genetic resources conservation, breeding practices, 
Table 5 Grouping of durian (Durio spp.) germplasm based on $\mathrm{ML}$ and NJ methods

\begin{tabular}{|c|c|c|c|}
\hline \multirow[t]{2}{*}{ Local name } & \multirow[t]{2}{*}{ Species } & \multicolumn{2}{|l|}{ Clade } \\
\hline & & ML & NJ \\
\hline Durian Sahang & D. zibethinus & । & । \\
\hline Kalih Haliyang & D. kutejensis & I & । \\
\hline Pampaken & D. kutejensis & I & । \\
\hline Pampaken Burung Kecil & D. kutejensis & I & । \\
\hline Durian Daun & D. lowianus & I & । \\
\hline Durian Malutu & D. lowianus & 1 & । \\
\hline Lahung Alang & D. lowianus & 1 & । \\
\hline Karantungan Besar & D. oxleyanus & 1 & । \\
\hline Durian Kura-Kura & D. testudinarium & 1 & । \\
\hline Durian Si Japang ${ }^{\mathrm{a}}$ & D. zibethinus & $\|$ & । \\
\hline Durian Likol & D. zibethinus & $\|$ & $\|$ \\
\hline LaiLidung & D. kutejensis & $\|$ & $\|$ \\
\hline Lahung & D. dulcis & $\|$ & $\|$ \\
\hline Maharawin Hamak & D. oxleyanus & $\|$ & $\|$ \\
\hline Durian Burung & D. acutifolius & III & III \\
\hline Durian Burung Besar & D. excelsus & III & III \\
\hline Kamundai & D. kutejensis & IV & IV \\
\hline Mantuala Batu Hayam & D. excelsus & IV & IV \\
\hline Indian Kapok & Bombax ceiba & Outgroup & Outgroup \\
\hline
\end{tabular}

${ }^{a}$ Inconsistent in grouping

and preventing genetic basis erosion of breeding populations [14]. For these purposes, examining genetic diversity is essential in managing threatened species or taxa [46]. According to Teixeira and Huber [43], conservation genetic practice rests on the assumption that measured levels of diversity provide a direct indicator of the degree to which genetic factors contribute to the risk of extinction. For crop improvement, genetic diversity is beneficial for parental selection [51] or selecting parents with genetically divergent [14]. In this context, determining populations with a high level of genetic diversity will become a valuable resource for broadening the genetic base or gene pool of germplasm, as this enables the identification of superior alleles for several traits [51].

Following the AMOVA (Table 4), the durian germplasm has a higher variation (94.38\%) at the intra-species level than the inter-species one (5.62\%). It means that the future durian breeding program can be oriented to outcrossing, as was done by Hariyati et al. [10] and Prihatini et al. [9]. According to Uji [6], several wild durian species, except $D$. zibethinus, have potential genes that can be incorporated into this program, such as being resistant to diseases and having a high tolerance for environmental challenges.

\section{Genetic relationship and divergence}

The phylogenetic study or genetic relationships is also beneficial for plant genetic conservation and breeding practices [14]. For the first program, this study can be applied in inferring species and their evolutionary history, including species delimitation, genetic differentiation, and gene flow [52]. In other words, this information is given the objective metrics for conservation purposes in the past evolution history, genetic status of species in the present time, and management program for future

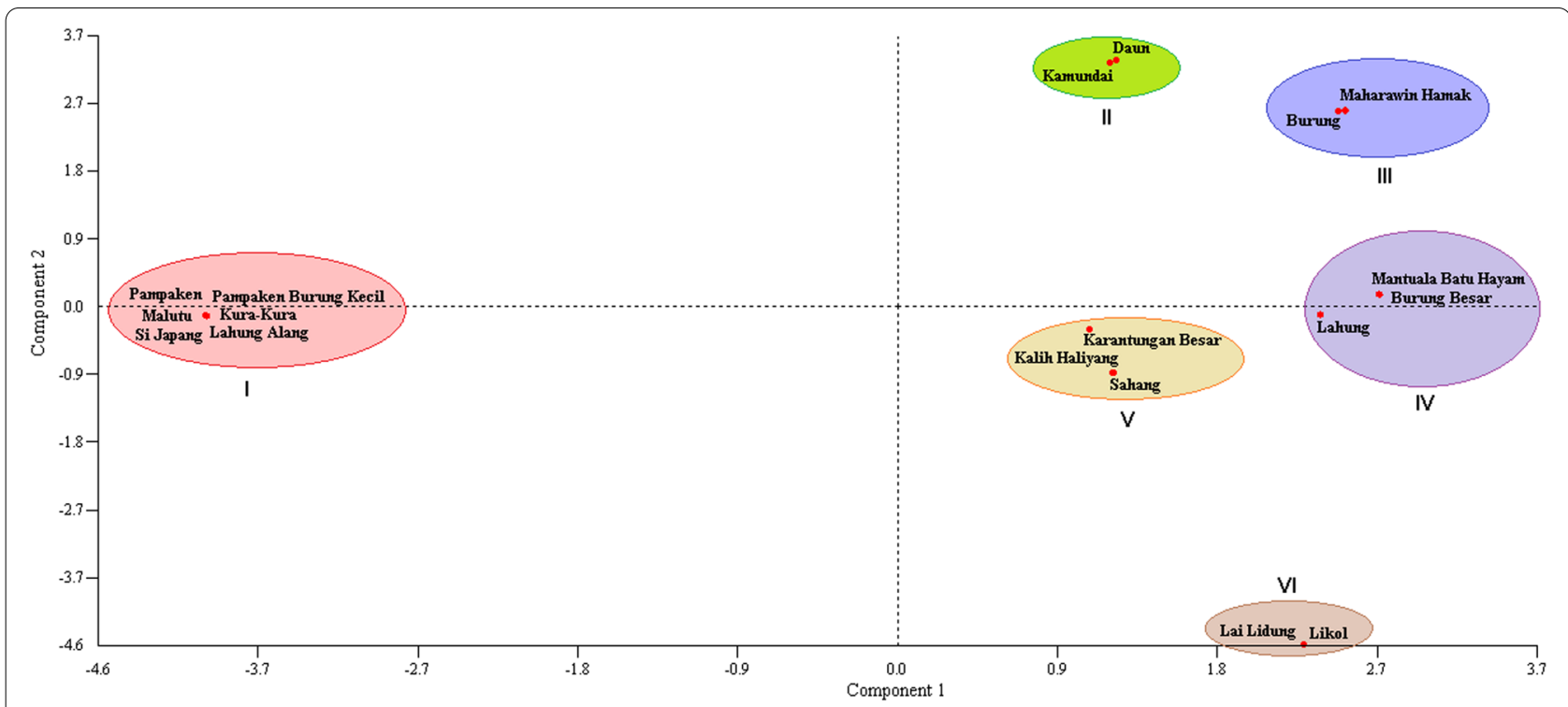

Fig. 6 Grouping of exotic durian (Durio spp.) germplasm revealed by principal component analysis (PCA) method 
Table 6 Genetic divergence among durian species (Durio spp.) used in this study

\begin{tabular}{lcccccccc}
\hline $\begin{array}{l}\text { Species group } \\
\text { (OTUs) }\end{array}$ & Code & A & B & C & D & E & F & G \\
\hline D. zibethinus & A & & & & & & & \\
D. kutejensis & $\mathrm{B}$ & 0.0017 & & & & & & \\
D. lowianus & $\mathrm{C}$ & 0.0012 & 0.0022 & & & & & \\
D. excelsus & $\mathrm{D}$ & 0.0042 & 0.0050 & 0.0053 & & & & \\
D. oxleyanus $^{* *}$ & $\mathrm{E}$ & 0.0006 & 0.0020 & 0.0015 & 0.0046 & & & \\
Other durians $^{*}$ & $\mathrm{~F}$ & 0.0032 & 0.0044 & 0.0042 & 0.0042 & 0.0035 & & \\
Bombax ceiba $^{*}$ & $\mathrm{G}$ & 0.0097 & 0.0103 & 0.0106 & 0.0130 & 0.0092 & 0.0143 & \\
\hline
\end{tabular}

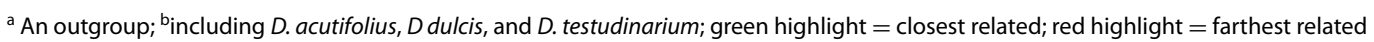

Table 7 Genetic divergence among all exotic durian (Durio spp.) germplasm used in this study

\begin{tabular}{|c|c|c|c|c|c|c|c|c|c|c|c|c|c|c|c|c|c|c|c|c|}
\hline OTUs & Code & $\mathbf{A}$ & B & $\mathbf{C}$ & $\mathbf{D}$ & $\mathbf{E}$ & $\mathbf{F}$ & $\mathbf{G}$ & $\mathbf{H}$ & $\mathbf{I}$ & $\mathbf{J}$ & $\mathbf{K}$ & $\mathbf{L}$ & $\mathbf{M}$ & $\mathbf{N}$ & $\mathbf{o}$ & $\mathbf{P}$ & $\mathbf{Q}$ & $\mathbf{R}$ & $\mathbf{s}$ \\
\hline Durian Burung (D. acutifolius) & A & & & & & & & & & & & & & & & & & & & \\
\hline Kalih Haliyang (D. kutejensis) & B & 0.011 & & & & & & & & & & & & & & & & & & \\
\hline Durian Burung Besar (D. excelsus) & $\mathrm{C}$ & 0.002 & 0.009 & & & & & & & & & & & & & & & & & \\
\hline Maharawin Hamak (D. oxleyanus) & $\mathrm{D}$ & 0.008 & 0.004 & 0.006 & & & & & & & & & & & & & & & & \\
\hline Mantuala Batu Hayam (D. excelsus) & E & 0.006 & 0.005 & 0.003 & 0.002 & & & & & & & & & & & & & & & \\
\hline Pampaken Burung Kecil (D. kutejensis) & $\mathrm{F}$ & 0.011 & 0.004 & 0.009 & 0.004 & 0.005 & & & & & & & & & & & & & & \\
\hline Malutu (D. lowianus) & G & 0.010 & 0.002 & 0.007 & 0.002 & 0.004 & 0.002 & & & & & & & & & & & & & \\
\hline Durian Kura-Kura (D. testudinarium) & $\mathrm{H}$ & 0.010 & 0.002 & 0.007 & 0.002 & 0.004 & 0.002 & 0.000 & & & & & & & & & & & & \\
\hline Duiran Daun (D. lowianus) & I & 0.010 & 0.002 & 0.007 & 0.002 & 0.004 & 0.005 & 0.004 & 0.004 & & & & & & & & & & & \\
\hline Lahung (D. dulcis) & $\mathrm{J}$ & 0.008 & 0.004 & 0.005 & 0.000 & 0.002 & 0.004 & 0.002 & 0.002 & 0.002 & & & & & & & & & & \\
\hline Lahung Alang (D. lowianus) & K & 0.010 & 0.002 & 0.007 & 0.002 & 0.004 & 0.002 & 0.000 & 0.000 & 0.004 & 0.002 & & & & & & & & & \\
\hline Karantungan Besar (D. oxleyanus) & $\mathrm{L}$ & 0.010 & 0.002 & 0.007 & 0.002 & 0.004 & 0.002 & 0.000 & 0.000 & 0.004 & 0.002 & 0.000 & & & & & & & & \\
\hline Pampaken (D. kutejensis) & M & 0.010 & 0.002 & 0.007 & 0.002 & 0.004 & 0.002 & 0.000 & 0.000 & 0.004 & 0.002 & 0.000 & 0.000 & & & & & & & \\
\hline Kamundai (D. kutejensis) & $\mathrm{N}$ & 0.006 & 0.005 & 0.004 & 0.002 & 0.000 & 0.005 & 0.004 & 0.004 & 0.004 & 0.002 & 0.004 & 0.004 & 0.004 & & & & & & \\
\hline Lai Lidung (D. kutejensis) & $\mathrm{O}$ & 0.008 & 0.004 & 0.005 & 0.000 & 0.002 & 0.004 & 0.002 & 0.002 & 0.002 & 0.000 & 0.002 & 0.002 & 0.002 & 0.002 & & & & & \\
\hline Durian Likol (D. zibethinus) & $P$ & 0.008 & 0.004 & 0.005 & 0.000 & 0.002 & 0.004 & 0.002 & 0.002 & 0.002 & 0.000 & 0.002 & 0.002 & 0.002 & 0.002 & 0.000 & & & & \\
\hline Durian Sahang (D. zibethinus) & Q & 0.010 & 0.002 & 0.007 & 0.002 & 0.004 & 0.002 & 0.000 & 0.000 & 0.004 & 0.002 & 0.000 & 0.000 & 0.000 & 0.004 & 0.002 & 0.002 & & & \\
\hline Durian Si Japang (D. zibethinus) & $\mathrm{R}$ & 0.008 & 0.002 & 0.006 & 0.000 & 0.002 & 0.002 & 0.000 & 0.000 & 0.002 & 0.000 & 0.000 & 0.000 & 0.000 & 0.002 & 0.000 & 0.000 & 0.000 & & \\
\hline Indian Kapok $(\text { Bombax ceiba })^{*}$ & $\mathrm{~s}$ & 0.011 & 0.012 & 0.019 & 0.008 & 0.007 & 0.012 & 0.011 & 0.011 & 0.011 & 0.021 & 0.011 & 0.011 & 0.011 & 0.007 & 0.009 & 0.009 & 0.011 & 0.010 & \\
\hline
\end{tabular}

${ }^{\mathrm{a}}$ An outgroup; green highlight $=$ closest related; red highlight $=$ farthest related

ones [52]. For the second or last purposes, information of this relationship is usable in predicting the genetic diversity of the offspring when individuals or populations cross [5].

In this study, the durian (Durio spp.) germplasm from Kalimantan, Indonesia, shows unique relationships, mainly based on the number and composition of durian members in each clade or group formed. In general, following the maximum likelihood (ML) and neighbor-joining (NJ) methods, this germplasm is grouped into four main clades (Figs. 4 and 5, respectively). According to the PCA, this germplasm was separated into six groups (Fig. 6). Interestingly, both for ML and NJ, most of the durian samples were consistent in the same clade, except for Durian Si Japang (D. zibethinus), which belongs to Clade II in ML and Clade I in NJ (Table 5). Briefly, these phylogenetic trees (Figs. 4 and 5) and grouping illustrated the closeness and distant relationship between the samples.

The divergence analysis (Table 6) showed that by species group, $D$. zibethinus was very closely related to $D$. exleyanus. Meanwhile, the farthest shows by $D$. lowianus and D. excelsus. By ITS and $n d h F$ markers, Nyffeler and Baum $[53,54]$ reported a close relationship between $D$. zibethinus and D. oxleyanus. Such relationships were also stated by Santoso et al. [55] using RFLP, Santoso et al. [12] by microsatellite, and Santoso et al. [56] with ITS.

However, within individuals (Table 7), 29 durian pairs are very closely related, and the farthest shown by Durian Burung (D. acutifolius) and Kalih Haliyang (D. kutejensis), and Pampaken Burung Kecil (D. kutejensis) with Durian Burung (D. acutifolius) as well, at a divergence coefficient of 0.011. Following the Pearson correlation analysis, only 20 pairs of individual durians have a strong 


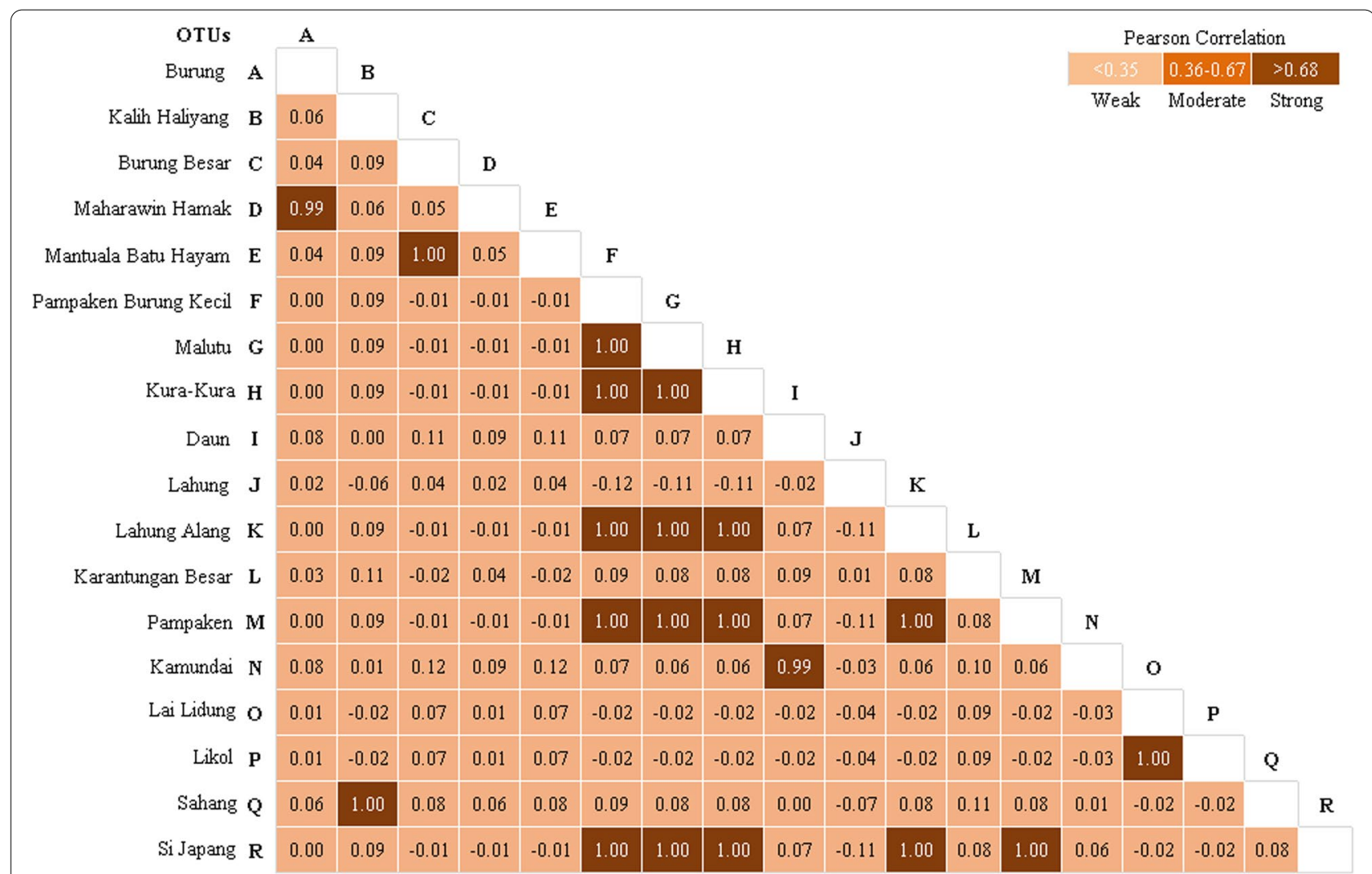

Fig. 7 Pearson correlation coefficient among exotic durian (Durio spp.) germplasm based on the rbcL region

relation, for example, Maharawin Hamak and Durian Burung as well as Mantuala Batu Hayam and Durian Burung Besar (Fig. 7). According to Acquaah [5], crossing individuals with distant relationships may generate high genetic diversity in the offspring. Conversely, crossing individuals with very close related may result in offspring with a low or narrow genetic diversity. In general, crossing individuals with a very close relationship is tends to avoid, as inbreeding occurs in the offspring [57]. Thus, our results are essential in supporting the future durian genetic conservation and breeding practices.

\section{Conclusion}

Following the $r b c \mathrm{~L}$ region, the exotic durian (Durio spp.) germplasm originally from Kalimantan, Indonesia, has a low genetic diversity $(\pi \%=0.24)$. However, following the phylogenetic and principal component analyses, this germplasm is separated into four main clades and six groups, respectively. In this case, D. zibethinus is very closely related to $D$. exleyanus. Meanwhile, $D$. lowianus and D. excelsus are the farthest. Individually, 29 durians were very closely related, and the was farthest shown by Durian Burung (D. acutifolius) and Kalih Haliyang (D. kutejensis) as well as also Pampaken Burung Kecil (D. kutejensis) and Durian Burung (D. acutifolius) with a divergence coefficient of 0.011 . The Pearson correlation analysis confirms that 20 pairs of individual durians have a strong relation, shown by (e.g.) Maharawin Hamak and Durian Burung, also Mantuala Batu Hayam and Durian Burung Besar. Our results may provide a fundamental paradigm in supporting the durian genetic conservation and breeding practices in the future, locally and globally.

\section{Abbreviations}

ITS: Internal transcribed spacer; ML: Maximum likelihood; NJ: Neighborjoining; PCA: Principal component analysis; RFLP: Restriction fragment length polymorphism.

\section{Acknowledgements}

We wish to thank Hanif Wicaksono for providing samples of durian leaves for this study. We also thank our colleagues at the Center for the Release and Certification of Seeds for Food Crops and Horticulture, South Kalimantan, Indonesia, for the information provided regarding the existence of these samples.

\section{Authors' contributions}

DHM conceptualized the overall research, designing and conducting the experiments, and final manuscript preparation. MIR carried out the sample collection, experimentation, data collection, and draft preparation. BZ assisted in partial conceptualization of the research work and contributed to the molecular data analysis. AN contributed in guiding the sample collection. All authors have read and approved the manuscript for publication. 


\section{Funding}

Not applicable.

\section{Availability of data and materials}

The datasets used and analyzed in the present study are presented in the article, and the $r b c L$ sequences of this germplasm were deposited in GenBank with accession numbers.

\section{Declarations}

\section{Ethics approval and consent to participate}

Not applicable.

\section{Consent for publication}

Not applicable.

\section{Competing interests}

The authors declare that they have no competing interests.

\begin{abstract}
Author details
${ }^{1}$ Laboratory of Genetics and Molecular Biology, Faculty of Mathematics and Natural Sciences, University of Lambung Mangkurat, J. A. Yani Km. 36, Banjarbaru, South Kalimantan 70714, Indonesia. ${ }^{2}$ Assessment Institute of Agricultural Technology, Jl. Panglima Batur Barat No. 4, Banjarbaru, South Kalimantan 70714, Indonesia.
\end{abstract}

Received: 27 October 2021 Accepted: 18 February 2022 Published online: 01 March 2022

\section{References}

1. Mursyidin DH, Daryono BS (2016) Genetic diversity of local durian (Durio zibethinus Murr.) cultivars of South Kalimantan's province based on RAPD markers. In: AIP Conference Proceedings

2. Rizaty MA (2021) National production of durian [Produksi durian nasional]. https://databoks.katadata.co.id/datapublish/2021/06/23/produ ksi-durian-di-indonesia-menurun-pada-2020

3. Statista Research Department (2021) Production of durian in Indonesia 2011-2020. https://www.statista.com/statistics/706504/production-ofdurian-in-indonesia/

4. Durian Harvests Indonesia (2021) Global durian production. https://www. durianharvestsindonesia.com/production/

5. Acquaah $\mathrm{G}$ (2007) Principles of plant genetics and breeding. Blackwell Publishing, Oxford

6. Uji T (2005) Species diversity and genetic resources of Durio (Durio spp.) in Indonesia [Keanekaragaman jenis dan sumber plasma nutfah Durio (Durio spp.) di Indonesia]. Buletin Plasma Nutfah 11:28-33

7. Uji T (2004) Species diversity, genetic resources, and potential of the indigenous fruits in Kalimantan [Keanekaragaman jenis, plasma nutfah, dan potensi buah-buahan asli Kalimantan]. Bio SMART 6:117-125

8. Jiang G-L (2013) Molecular markers and marker-assisted breeding in plants. In: Plant breeding from laboratories to fields. InTech Open Ltd. London, pp 44-83

9. Prihatini R, Ihsan F, Indriyani NLP (2016) Genomic profiling of F1 hybrids of durian (Durio zibethinus) revealed by RAPD-PCR. J Hort Res 24:69-76. https://doi.org/10.1515/johr-2016-0022

10. Hariyati T, Kusnadi J, Arumingtyas EL (2013) Genetic diversity of hybrid durian resulted from cross-breeding between Durio kutejensis and Durio zibethinus based on random amplified polymorphic DNAs (RAPDs). Amer J Mol Biol 03:153-157. https://doi.org/10.4236/ajmb.2013.33020

11. Ho VT, Ho MD, Tran TL (2020) Characterizing genetic variation of two popular durians (Durio zibethinus L.) varieties in southern Vietnam by using ISSR markers. Biosci Res 17:3040-3049

12. Santoso PJ, Granitia A, Indriyani NLP, Pancoro A (2016) Loci analysis and diversity of durian (Durio sp.) germplasm based on microsatellite markers [Analisis lokus dan keragaman sumber daya genetik durian (Durio sp.) berdasarkan marka mikrosatelit]. J Hort 26:9-20

13. Lee SC, Wang CH, Yen CE, Chang C (2017) DNA barcode and identification of the varieties and provenances of Taiwan's domestic and imported made teas using ribosomal internal transcribed spacer 2 sequences. J Food Drug Anal 25:260-274. https://doi.org/10.1016/j.jfda.2016.06.008

14. Wu F, Ma S, Zhou J et al (2021) Genetic diversity and population structure analysis in a large collection of white clover (Trifolium repens L.) germplasm worldwide. PeerJ 9:1-17. https://doi.org/10.7717/peerj. 11325

15. Moura CCDM, Brambach F, Bado KJH et al (2019) Integrating DNA barcoding and traditional taxonomy for the identification of dipterocarps in remnant lowland forests of Sumatra. Plants 8:1-14. https://doi.org/ 10.3390/plants8110461

16. Singh J, Kakade DP, Wallalwar MR et al (2017) Evaluation of potential DNA barcoding loci from plastid genome: intraspecies discrimination in rice (Oryza species). Intl J Curr Microbiol Appl Sci 6:2746-2756. https://doi.org/10.20546/ijcmas.2017.605.308

17. Hollingsworth PM, Li DZ, van der Bank M, Twyford AD (2016) Telling plant species apart with DNA: from barcodes to genomes. Philos Trans R Soc B Biol Sci 371. https://doi.org/10.1098/rstb.2015.0338

18. Mursyidin DH, Nazari YA, Badruzsaufari, Masmitra MRD (2021) DNA barcoding of the tidal swamp rice (Oryza sativa) landraces from South Kalimantan, Indonesia. Biodiv 22:1593-1599. https://doi.org/10.13057/ biodiv/d220401

19. Mursyidin DH, Hernanda MA (2021) Phylogenetic positions of three Amorphophallus species natively growing in the Meratus Mountains, South Kalimantan, Indonesia. Biodiversitas 22:2821-2828. https://doi. org/10.13057/biodiv/d220546

20. Akilabindu K (2019) Genomic analysis of chloroplast matK and rbcL gene from Flacourtia inermis Roxb for plant DNA barcoding. GSC Biol Pharma Sci 9:065-071. https://doi.org/10.30574/gscbps.2019.9.2.0177

21. Yao X, Tan YH, Yang JB et al (2019) Exceptionally high rates of positive selection on the rbcL gene in the genus /lex (Aquifoliaceae). BMC Evol Biol 19:1-13. https://doi.org/10.1186/s12862-019-1521-1

22. Gholave AR, Pawar KD, Yadav SR et al (2017) Reconstruction of molecular phylogeny of closely related Amorphophallus species of India using plastid DNA marker and fingerprinting approaches. Physiol Mol Biol Plants 23:155-167. https://doi.org/10.1007/s12298-016-0400-0

23. Kumar S, Stecher G, Li M et al (2018) MEGA X: molecular evolutionary genetics analysis across computing platforms. Mol Biol Evol 35:15471549. https://doi.org/10.1093/molbev/msy096

24. Sievers F, Barton G, Higgins DG (2020) Multiple sequence alignments. In: Baxevanis A (ed) Bioinformatics. Wiley, New Jersey

25. Mitchell C (1993) MultAlin: multiple sequence alignment. Cabios Soft Rev 9:614-615

26. Nei M, Li WH (1979) Mathematical model for studying genetic variation in terms of restriction endonucleases (molecular evolution/mitochondrial DNA/nucleotide diversity). PNAS 76:5269-5273

27. Lemey P, Salemi M, Vandamme AM (2009) The phylogenetic handbook: a practical approach to phylogenetic analysis and hypothesis testing, second. Cambridge University Press, Cambridge

28. Kovach W (1999) MVSP-a multivariate statistical Package for Windows, ver. 3.1. Kovach Computing Services, Pentraeth, p 137

29. Kimura M (1980) A simple method for estimating evolutionary rates of base substitutions through comparative studies of nucleotide sequences. J Mol Evol 16:111-120

30. Excoffier L, Lischer HEL (2010) Arlequin suite ver 3.5: a new series of programs to perform population genetics analyses under Linux and Windows. Mol Ecol Resour 10:564-567. https://doi.org/10.1111/j.17550998.2010.02847.x

31. Taylor R (1990) Interpretation of the correlation coefficient: a basic review. J Diagn Med Sonogr 6:35-39. https://doi.org/10.1177/87564 7939000600106

32. Liu L, Zhao B, Zhang Y, Wang J (2012) Adaptive evolution of the rbcL gene in Brassicaceae. Biochem Syst Ecol 44:13-19. https://doi.org/10. 1016/j.bse.2012.04.007

33. Dong W, Cheng T, Li C et al (2014) Discriminating plants using the DNA barcode rbcLb: an appraisal based on a large data set. Mol Ecol Resour 14:336-343. https://doi.org/10.1111/1755-0998.12185

34. Singh J, Banerjee S (2018) Utility of DNA barcoding tool for conservation and molecular identification of intraspecies of rice genotypes belonging to Chhattisgarh using $\mathrm{rbcL}$ and matK gene sequences. Plant Arch 18:69-75 
35. CBOL Plant Working Group (2009) A DNA barcode for land plants. PNAS 106:12794-12797

36. Kumekawa Y, Kilmaskossu M, Mori M et al (2014) Changes in plant species during succession in a sago forest. Amer J Plant Sci 05:3526-3534. https://doi.org/10.4236/ajps.2014.524369

37. Amandita FY, Rembold K, Vornam B et al (2019) DNA barcoding of flowering plants in Sumatra, Indonesia. Ecol Evol 9:1858-1868. https://doi.org/ 10.1002/ece3.4875

38. Alverson WS, Karol KG, Baum DA et al (1998) Circumscription of the Malvales and relationships to other Rosidae: evidence from $\mathrm{rbcL}$ sequence data. Amer J Bot 85:876-887. https://doi.org/10.2307/2446423

39. Clegg MT (1993) Chloroplast gene sequences and the study of plant evolution. PNAS 90:363-367

40. Dong ZZ, Fan X, Sha LN et al (2013) Phylogeny and molecular evolution of the rbcL gene of St genome in Elymus sensu lato (Poaceae: Triticeae). Biochem Syst Ecol 50:322-330. https://doi.org/10.1016/j.bse.2013.05.005

41. Bousquet J, Strauss S, Doerksen A, Price R (1992) Extensive variation in evolutionary rate of rbcL gene sequences among seed plants. PNAS 89:7844-7848

42. Berger JD, Buirchell BJ, Luckett DJ, Nelson MN (2012) Domestication bottlenecks limit genetic diversity and constrain adaptation in narrow-leafed lupin (Lupinus angustifolius L.). Theor Appl Genet 124:637-652. https:// doi.org/10.1007/s00122-011-1736-z

43. Teixeira JC, Huber CD (2021) The inflated significance of neutral genetic diversity in conservation genetics. PNAS 118:1-10. https://doi.org/10. 1073/pnas.2015096118/-/DCSupplemental

44. Furlan E, Stoklosa J, Griffiths J et al (2012) Small population size and extremely low levels of genetic diversity in island populations of the platypus, Ornithorhynchus anatinus. Ecol Evol 2:844-857. https://doi.org/ 10.1002/ece3.195

45. Ujvari B, Klaassen M, Raven N et al (2018) Genetic diversity, inbreeding and cancer. Proc R Soc B Biol Sci 285:1-8. https://doi.org/10.1098/rspb. 2017.2589

46. Kleinhans C, Willows-Munro S (2019) Low genetic diversity and shallow population structure in the endangered vulture, Gyps coprotheres. Sci Rep 9:1-11. https://doi.org/10.1038/s41598-019-41755-4

47. Frankham R, Ballou JD, Broscoe DA (2004) A primer of conservation genetics. Cambridge University Press, Cambridge

48. Guo C, McDowell IC, Nodzenski M et al (2017) Transversions have larger regulatory effects than transitions. BMC Genomics 18:1-9. https://doi. org/10.1186/s12864-017-3785-4

49. Stoltzfus A, McCandlish DM (2017) Mutational biases influence parallel adaptation. Mol Biol Evol 34:2163-2172. https://doi.org/10.1093/molbev/ $\mathrm{ms} \times 180$

50. Stoltzfus A, Norris RW (2016) On the causes of evolutionary transition: transversion bias. Mol Biol Evol 33:595-602. https://doi.org/10.1093/ molbev/msv274

51. Aesomnuk W, Ruengphayak S, Ruanjaichon V et al (2021) Estimation of the genetic diversity and population structure of Thailand's rice landraces using SNP markers. Agron 11:995. https://doi.org/10.3390/agronomy11 050995

52. Fernández-García JL (2017) Phylogenetics for wildlife conservation. In: Phylogenetics. InTech, UK

53. Nyffeler R, Baum DA (2000) Phylogenetic relationships of the durians (Bombacaceae-Durioneae or /Malvaceae/Helicteroideae/Durioneae) based on chloroplast and nuclear ribosomal DNA sequences. Plant Sys Evol 224:55-82

54. Nyffeler R, Baum DA (2001) Systematics and character evolution in Durio s. lat.(Malvaceae/Helicteroideae/Durioneae or Bombacaceae-Durioneae). Org Divers Evol 1:165-178

55. Santoso PJ, Saleh GB, Saleh NM, Napis S (2005) Phylogenetic relationships amongst 10 Durio species based on PCR-RFLP analysis of two chloroplast genes. Indon J Agric Sci 6:20-27

56. Santoso PJ, Indriyani NLP, Istianto M et al (2017) Phylogeny of Indonesian durian (Durio sp.) germplasm based on polymorphism of ITS-nrDNA sequences. Acta Hort 1186:35-41. https://doi.org/10.17660/ActaHortic. 2017.1186.5

57. de Los Reyes BG (2019) Genomic and epigenomic bases of transgressive segregation - New breeding paradigm for novel plant phenotypes. Plant Sci 288:1-10. https://doi.org/10.1016/j.plantsci.2019.110213

\section{Publisher's Note}

Springer Nature remains neutral with regard to jurisdictional claims in published maps and institutional affiliations.

\section{Submit your manuscript to a SpringerOpen ${ }^{\circ}$ journal and benefit from:}

- Convenient online submission

- Rigorous peer review

- Open access: articles freely available online

- High visibility within the field

- Retaining the copyright to your article

Submit your next manuscript at $\boldsymbol{\nabla}$ springeropen.com 